\title{
Ultralow volume application of organophosphate concentrate in grain terminals: a new occupational health hazard
}

\author{
R T GUN,' C GRYCORCEWICZ,' A J ESTERMAN, ${ }^{2}$ J B EDWARDS ${ }^{3}$ \\ From the Occupational Health and Radiation Control Branch and Epidemiology Branch, ${ }^{2} S$ A Health \\ Commission, Adelaide, and Institute of Medical and Veterinary Science, ${ }^{3}$ Adelaide, South Australia 5000
}

ABSTRACT The introduction of ultralow volume (ULV) application of the organophosphate pesticide Fenitrothion in grain terminals presents a risk to workers of skin contact with concentrate. Blood testing, by the Ellman method, of a group of five grain terminal workers working on grain treatment showed a lowering of mean red blood cell cholinesterase (RBC ChE) activity to 23 units/gm $\mathrm{Hb}$ (normal value 28-40) with a range of 16-29. The probable cause was identified as percutaneous absorption of Fenitrothion concentrate by workers using ungloved hands to clean blocked drip feed nozzles. Modification of work practices was followed by a rise of mean RBC ChE to $33.6 \mathrm{units} / \mathrm{gm} \mathrm{Hb}$ (range 32-36) during the following grain treatment season. RBC ChE activity measured during the intervening winter season-that is, a non-exposure period-showed a mean of $33.3 \mathrm{units} / \mathrm{gm} \mathrm{Hb}$ (range 23-40).

Organophosphates are irreversible inhibitors of cholinesterase activity, producing powerful and continuous cholinergic effects. Acute poisoning is not uncommon after ingestion of the concentrate, usually by accident or by a suicidal act, ${ }^{1}$ and is characterised by respiratory, ocular, and gastrointestinal effects. Such episodes, however, do not usually occur from occupational exposures.

Although these substances have been used for many years as pesticides in grain terminals, little mention has been made of their toxic effects in this environment. Most medical reports on these workers has focused on respiratory effects of the grain dust itself, ${ }^{23}$ although recent reference has been made to the problem of atmospheric contamination with organophosphates. ${ }^{4}$

In the early 1980s a method of ultralow volume (ULV) pesticide spraying was introduced into South Australia. The practice of spraying high volumes of diluted pesticide on to the grain was replaced by drip feeding small volumes of concentrate. While this greatly reduced the concentration of airborne pesticide, it presented a risk of potential skin contact of workers with the concentrate.

The following is a description of a problem of exposure to organophosphates identified in a grain terminal and its correction by a simple modification of work practice.

Accepted 9 November 1987

\section{Sequence of events}

After a request from the Australian Workers' Union, an investigation was made into symptoms experienced by three workers at a country grain terminal in May 1985 , about three years after the introduction of ULV application.

The symptoms were mainly respiratory and were believed to be at least partly related to exposure to grain dust. It was decided, however, to monitor the cholinesterase activity in workers during the following summer, when the grain from the next harvest would be treated with the organophosphate Fenitrothion.

Accordingly, in January 1986 blood testing was carried out at one terminal on five workers who were all engaged in grain treatment. The tests indicated depression of red blood cell cholinesterase (RBC ChE) activities.

To check the significance of the RBC ChE activities, similar tests were undertaken during the winter months of 1986, when the organophosphates were not in use. At this time all 16 workers at the grain terminal were tested. Meanwhile the ULV application procedure was examined and potential sources of exposure to organophosphate were identified. Procedures were then introduced to eliminate the causes of exposure.

To test the effectiveness of these measures, further 


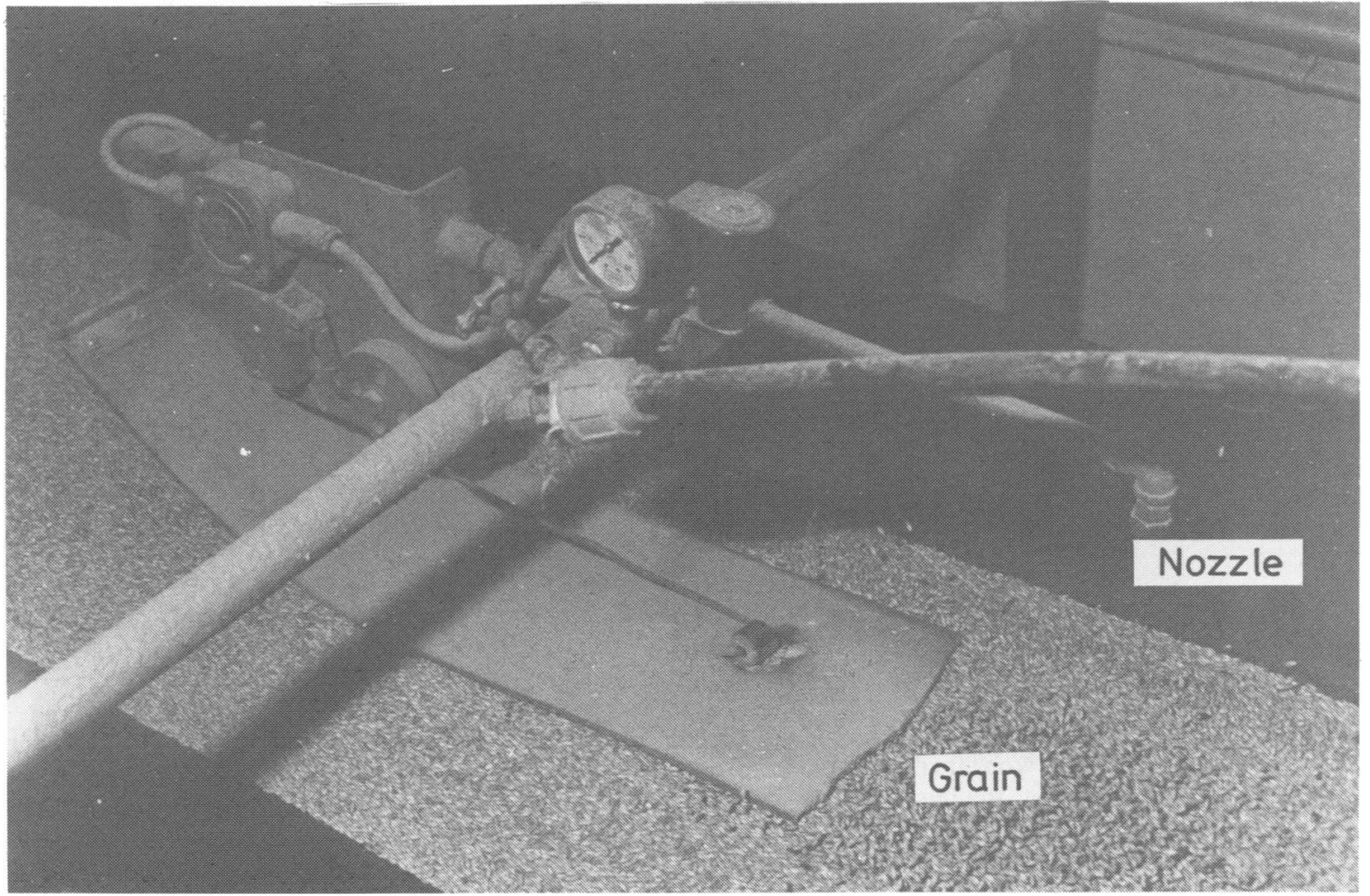

Fig 1 Drip feed system for application of organophosphate concentrate to grain.

blood testing was carried out during the next treatment of grain received in January 1987.

\section{Identifying and controlling the exposure to organophosphates}

Two potential sources of exposure to organophosphates were identified during inspection of the process. One source was the metering pumps conveying the concentrate. These required periodic changing of their plastic hoses, with potential for skin contact. This problem was eliminated by replacing the plastic hoses with fixed copper tubing.

A more important source of skin contamination was the nozzle of the dispensers by which the concentrate is delivered on to the grain (figs 1 and 2). The filters in the nozzle frequently become caked with grain dust and blocked up, requiring the nozzles to be removed and cleaned. Workers were provided with gloves for this procedure, but because of the slipperiness of the organophosphate concentrate and the need to disassemble small components of the nozzles, they found the task difficult to perform and often removed their gloves.

This problem was simply overcome by making available a spare clean nozzle and filter. A blocked nozzle would be removed with a spanner (with the hands gloved) and the spare nozzle fitted. The blocked nozzle and filter is dropped into a hypochlorite solution after which it may be thoroughly and safely cleaned at leisure without interrupting the grain treatment.

\section{Blood testing}

As explained above, blood samples were collected on five occasions: once near the end of grain treatment in January 1986, three times in the winter months 1986 (control period), May, June, and August and once near the end of grain treatment in January 1987 . The blood was tested for RBC ChE and for plasma cholinesterase, using a modification of the Ellman method. $^{s}$

The results of RBC ChE testing are given in the table.

The results for January 1986 show a significantly lower mean RBC ChE compared with the mean for the 1986 winter (non-treatment) period 1986. The mean RBC ChE of 23.6 units/gm $\mathrm{Hb}$ was well below the normal range of $28-40$ units/gm $\mathrm{Hb}$. The individual 

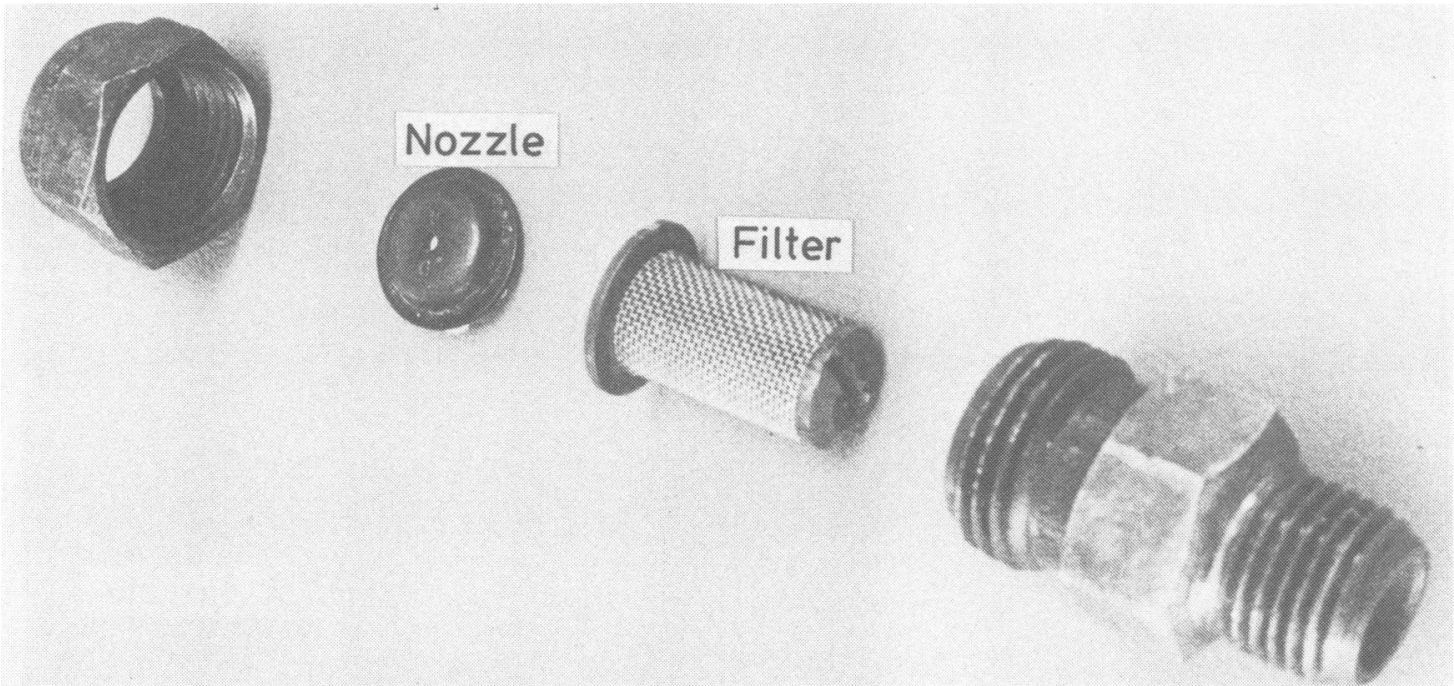

Fig 2 Drip feed nozzle and filter disassembled.

$\mathrm{RBC}$ ChE levels for the five workers ranged from 16 to 29 units/gm Hb. By contrast, the mean RBC ChE for January 1987, after corrective action had been taken, was well within normal limits (mean 33.6 units/gm Hb, range 32-36).

Some variation was noted between the three nontreatment months. The mean for May $1986(27 \cdot 8)$ was less than those for June (37.0) and August (35.2), a significant difference $(p<0.01)$. The low mean RBC $\mathrm{ChE}$ in May was probably due to the analytical technique rather than a residual organophosphate effect. Three of the workers with low levels in January 1986 were also tested at various times in February 1986 and had already shown sharp rises in RBC ChE-to 39, 39, and 42 units/gm Hb. Furthermore, an analysis of variance of all 16 grain terminal workers, including the non-exposed, showed significantly lower intraindividual RBC ChE levels in May compared with July and August.

Overall, despite some statistical "noise" associated with the analytical technique, the results suggested

Red blood cell cholinesterase levels (in units/gm $\mathrm{Hb}$ ) in relation to grain treatment with Fenitrothion. (Number of workers $=5$ )

\begin{tabular}{|c|c|c|c|c|}
\hline $\begin{array}{l}\text { Test } \\
\text { period }\end{array}$ & $\begin{array}{l}\text { Grain } \\
\text { treatment }\end{array}$ & $\begin{array}{l}\text { Mean } R B C \\
\text { activity, un } \\
\text { (2 standar }\end{array}$ & $\begin{array}{l}\text { ChE } \\
\text { s/gm } H b \\
\text { errors) }\end{array}$ & $\begin{array}{l}\text { Range } \\
\text { (normal } \\
=28-40)\end{array}$ \\
\hline $\begin{array}{l}\text { Jan } 86 \\
\text { May } 86 \\
\text { June } 86 \\
\text { Aug } 86 \\
\text { Jan } 87\end{array}$ & $\begin{array}{l}\text { OP Treatment } \\
\text { No treatment } \\
\text { No treatment } \\
\text { No treatment } \\
\text { OP treatment }\end{array}$ & $\begin{array}{l}23.6(5.0) \\
27.8(3.3) \\
37.0(2.7) \\
35.2(3.0) \\
33.6(1.6)\end{array}$ & $\begin{array}{l}\text { Mean for } \\
\text { non-treatment } \\
\text { period } 33 \cdot 3(2 \cdot 6)\end{array}$ & $\begin{array}{l}16-29 \\
23-33 \\
34-38 \\
30-38 \\
32-36\end{array}$ \\
\hline
\end{tabular}

that a significant fall in $\mathrm{RBC} C \mathrm{ChE}$ occurred at the time of the 1986 treatment with organophosphates, a fall that did not recur in 1987 after corrective action.

No significant variations occurred in the levels of plasma cholinesterase.

\section{Discussion}

Three routes of organophosphate intake are possible: inhalation (either by itself as a mist or on particles of grain dust), percutaneous absorption, or ingestion from eating or smoking with contaminated fingers. The change in technique from aerosol spraying of the grain to ULV application by drip feed would greatly reduce the potential for inhalation. Nevertheless, the use of organophosphate concentrate in the ULV application presents the potential for percutaneous absorption-a major mechanism of uptake of pesticides including organophosphates ${ }^{6}$-if the drip feed apparatus is handled without skin protection. Contamination of a small area of skin with concentrate is obviously equivalent to a large area of contamination of the solution used previously. Accordingly, the introduction of the ULV method, with the attendant requirement for handling small parts by hand, increases the risk of organophosphate poisoning.

Although no verifiable incident of organophosphate poisoning with symptoms occurred, the introduction of ULV spraying probably increased worker exposure. Long term effects of exposure to organophosphates are not well documented, although there have been reports of a variety of effects including impaired neuromuscular function ${ }^{7}$ and psychiatric effects. ${ }^{8}$ It is 
therefore prudent to avoid absorbing organophosphates, since exposures insufficient to cause acute toxic effects may represent a long term hazard. (A major, multinational study of the neurological effects of long term, low level exposure to organophosphates is presently being established under the auspices of WHO and the UN Development Program.')

The results suggest that $\mathrm{RBC} C \mathrm{ChE}$ is a more useful exposure index than plasma cholinesterase (PChE). This may be due to a rapid recovery in PChE levels after exposure, so that a fall is not likely to be detected unless a blood sample is collected almost immediately after exposure to organophosphates. On the other hand, RBC ChE levels recover more slowly, as the circulating red cells are "turned over."

The results also point to variations in the $\mathrm{RBCChE}$ activity measured by the Ellman method. Thus the mean activity for May 1986 was significantly lower than the means for June 1986 and August 1986, although May was a non-treatment period. The lower mean in May 1986 could result from contamination from an unrecorded use of an organophosphate, but a more likely explanation is that the analytical technique leads to a systematic variation between blood samples.

The analysis of variance shows that RBC ChE values vary between individuals. This illustrates the importance of serial measurements in evaluating effects in individuals.

\section{References}

1 Poisons Information Centre, Adelaide Children's Hospital Poisoning cases, poisoning telephone enquiries, 1986. Adelaide: Pic, 1986.

2 do Pico GA, Reddan W, Anderson S, Flaherty D, Smalley E. Acute effects of grain dust exposure during a workshift. Am Rev Respir Dis 1983;128:399-404.

3 Broder I, Hutcheon MA, Mintz S. Changes in respiratory variables of grain handlers and civic workers during their initial months of employment. Br J Ind Med 1984;41:94-9.

4 Palmgren MS, Lee TC. Malathion and diazinon levels in grain dust from New Orleans area grain elevators. Am Ind Hyg Assoc J 1984;45:168-71.

5 Ellman GL, Courtney KD, Andres V, Featherstone RM. A new and rapid colorimetric determination of acetylcholinesterase activity. Biochem Pharmacol 1961;7:88-97.

6 Franklin CA, Muir NI, Moody RP. The use of biological monitoring in the estimation of exposure during the application of pesticides. Toxicol Lett 1986;33:127-36.

7 Jager KW, Roberts DV, Wilson A. Neuromuscular function in pesticide workers. Br J Ind Med 1970;27:273-8.

8 Gershon S, Shaw FH. Psychiatric sequelae of chronic exposure to organophosphorous insecticides, Lancet 1961;i:1371-4.

9 Maroni M, Jarvisalo J, La Ferla E. The WHO-UNDP epidemiological study on the health effects of exposure to organophosphorous pesticides. Toxicol Lett 1986; 33:115-23.

10 Milby TH. Prevention and management of organophosphate poisoning. JAMA 1971;216:2131-3.

\section{Vancouver style}

All manuscripts submitted to the $\mathrm{Br} J$ Ind Med should conform to the uniform requirements for manuscripts submitted to biomedical journals (known as the Vancouver style)

The $\mathrm{Br} J$ Ind Med, together with many other international biomedical journals, has agreed to accept articles prepared in accordance with the Vancouver style. The style (described in full in $\mathrm{Br}$ Med J, 24 February 1979, p 532) is intended to standardise requirements for authors.

References should be numbered consecutively in the order in which they are first mentioned in the text by Arabic numerals above the line on each occasion the reference is cited (Manson ${ }^{1}$ confirmed other reports ${ }^{2-5} \ldots$.). In future references to papers submitted to the $\mathrm{Br} J$ Ind Med should include: the names of all authors if there are six or less or, if there are more, the first three followed by $e t$ al; the title of journal articles or book chapters; the titles of journals abbreviated according to the style of Index Medicus; and the first and final page numbers of the article or chapter.

Examples of common forms of references are:

1 International Steering Committee of Medical Editors. Uniform requirements for manuscripts submitted to biomedical journals. Br Med J 1979;1:532-5.

2 Soter NA, Wasserman SI, Austen KF. Cold urticaria: release into the circulation of histamine and eosino-phil chemotactic factor of anaphylaxis during cold challenge. $N$ Engl J Med 1976;294:687-90.

3 Weinstein L, Swartz MN. Pathogenic properties of invading micro-organisms. In: Sodeman WA Jr, Sodeman WA, eds. Pathologic physiology: mechanisms of disease. Philadelphia: W B Saunders. 1974:457-72. 